\title{
Retrospective Analysis of 185 Occurrences of Clinical Neurological Signs in 181 South American Camelids
}

\author{
Whitehead $\mathrm{CE}^{* 1,3}$, Anderson $\mathrm{DE}^{1,4}$ and Saville WJA
}

${ }^{1}$ Department of Veterinary Clinical Sciences, College of Veterinary Medicine, The Ohio State University, Columbus, USA

${ }^{2}$ Department of Preventive Medicine, College of Veterinary Medicine, The Ohio State University, USA

${ }^{3}$ Camelid Veterinary Services Ltd, The Old Barracks, Lady Grove, Goring Heath, Reading, UK

${ }^{4}$ Department of Large Animal Clinical Sciences, College of Veterinary Medicine, University of Tennessee, USA

${ }^{*}$ Corresponding author: Whitehead CE, BVM\&S MS Dip. ACVIM, Department of Veterinary Clinical Sciences, College of Veterinary Medicine, The Ohio State University, 601 Vernon L Tharp St, Columbus, OH 43210, USA, and Camelid Veterinary Services Ltd, The Old Barracks, Lady Grove, Goring Heath, Reading, RG8 7RU, UK, E-mail: claire@ukalpacavet.com

Citation: Whitehead CE, Anderson DE, Saville WJA (2018) Retrospective Analysis of 185 Occurrences of Clinical Neurological Signs in 181 South American Camelids. J Vet Sci Ani Husb 6(1): 103. doi: 10.15744/23489790.6.103

Received Date: January 03, 2018 Accepted Date: February 26, 2018 Published Date: February 28, 2018

\begin{abstract}
Objective: To review neurological disease in llamas and alpacas.

Design: Retrospective study.

Sample Population: All cases of neurological disease in llamas and alpacas presenting between February 1993 and October 2003.

Procedures: Medical records database analysis.

Results: Medical records of each occurrence of neurologic signs in 181 South American Camelids admitted on 185 occasions (90 alpacas and 95 llamas) were evaluated. Age ranged from 0 days to 20 years, but $70.5 \%$ of cases were $\geq 1$ year old. Specific clinical diagnosis was achieved by cerebrospinal fluid analysis (CSF), radiographs, computed tomography, laboratory testing, or necropsy in $74 \%$ of cases. $54 \%$ of cases survived; $46 \%$ of cases died or were euthanized. The most common diagnosis (31\%) was parasitic myelopathy/encephalopathy (PME). CSF eosinophilia $\geq 10 \%$ was found in $85 \%$ of parasitic spinal migrations but only in $55 \%$ of intracranial migrations, and 73\% had increased protein in CSF. There was a seasonal bias for PME with 79\% of cases occurring between October and March. Survival of PME cases was 77\% for spinal migration but only 7\% when intracranial migration occurred. The most common diagnoses, excluding PME, were infectious disease (15\%) and trauma (12\%). Most trauma cases involved the cervical spine of which $50 \%$ survived.

Conclusion and Clinical Relevance: Neurological disease is common in llamas and alpacas. The differential diagnoses list should be adjusted for patient age and seasonal influences. CSF analysis and computed tomography are useful diagnostic tools to differentiate causes of neurologic disease in llamas and alpacas.
\end{abstract}

Keywords: Llama, Alpaca, Neurologic disease, Brain, Spinal cord

List of Abbreviations: CK: Creatine kinase; CNS: Central nervous system; CSF: Cerebrospinal fluid; CT: Computed tomography; EHV-1: Equine herpesvirus-1; PME: Parasitic myelopathy/encephalopathy

\section{Introduction}

The presentation of neurological disease in South American Camelids, mainly llamas and alpacas, is common A wide range of neurological diseases have been described to occur in camelids [1-20]. However, comparisons of clinical, diagnostic, therapeutic and outcome data across these disorders is lacking. Further an examination of the epidemiologic features of these diseases is needed to further elucidate risk factors associated with the occurrence of these disorders. The composition of CSF in healthy, adult llamas has previously been described [21]. Cerebrospinal fluid analysis also has been shown to be valuable in the diagnosis 
of parasitic infestations of the central nervous system. Although the diseases affecting the central nervous system of camelids are diverse, parasitic infestation is among the most common and life-threatening. A recent study neurological disease caused by cerebrospinal namatodiasis in 11 alpacas and 9 llamas reported that only $45 \%$ of the affected camelids survived. We hypothesized that the differential diagnosis of various neurological diseases of camelids can be improved by careful examination of risk factors, diagnostic tests, and outcome variables. The objectives of this study were to describe and characterize the neurological diseases seen in llamas and alpacas residing in a geographical region of the northeastern part of the United State and to describe the typical CSF findings for the presenting diseases, and to identify prognostic information based on the patient's diagnosis. Because infestation with Parelaphostrongylus tenuis (parasitic myelopathy/encephalopathy; PME) is often considered a primary differential diagnosis, one aspect of this study was to determine its frequency when compared with other diagnoses and to compare clinical and pathologic findings with cases determined not to be PME. In addition, the study hoped to determine features of CSF useful as diagnostic tools.

\section{Materials and Methods}

\section{Case Selection}

A computer-assisted search was conducted to find all medical records coded as a llama or alpaca and marked with a diagnosis of neurologic disease. Each medical record was critically reviewed to determine if detailed information regarding history, physical examination, diagnostic tests, treatment, and outcome were present and consistent with neurological disease. For the purposes of case inclusion criterion, each case admission for each animal that presented for a different neurological disorder was treated as a new event. For example, if an alpaca was presented for heat stress in a given year and represented because of otitis/interna media at a later date, these cases were independently analysed. If a case represented for the same diagnosis, the recurrent case was considered as a continuation of the initial diagnosis. For example, a llama that presented for parasitic myelitis and recovered but then represented for the same problem was analysed as a single occurrence. All cases meeting these inclusion criteria were entered into the database for statistical evaluation.

\section{Medical Records Review}

The medical case records for llamas and alpacas presenting to the Veterinary Teaching Hospital at The Ohio State University and having neurological signs between February 1993 and October 2003 were reviewed. Data recorded from each case included: age, date (month and season) of presentation, gender, species, location of the farm of origin, history and clinical signs, results of CSF analysis if available, the clinical or definitive diagnosis, and discharge status. Whenever CSF results were available, hematological findings were also recorded provided these were taken within one day of the CSF sample. This was in order that a comparison of cell types could be made in the case of a blood-contaminated sample. Animals were classified into the following age groups: neonates $<2$ months; crias aged $2<6$ months; weanlings $6<12$ months; juveniles $12<24$ months; and adults older than 24 months.

The concentrations of protein and CK and white cell count and differential were recorded. CSF protein concentration was assigned into categories for statistical analysis with a protein concentration being considered normal up to and including 50mg/dl, mild/ moderately increased at $51-100 \mathrm{mg} / \mathrm{dl}$ and severely increased at more than $100 \mathrm{mg} / \mathrm{dl}$. Creatine kinase was similarly categorized into normal ( $\leq 15 \mathrm{IU} / \mathrm{L})$ or increased $(>15 \mathrm{IU} / \mathrm{L})$. These categories were based on normal values established for healthy llamas [21]. Eosinophilia of the CSF was categorized into normal ( $0 \%$ eosinophils), mildly increased (1-9\% eosinophils), moderately increased (10-69\% eosinophils), or severely increased (at least 70\% eosinophils). A CSF tap was considered clean if there were $\leq 100$ red blood cells per microliter, mild to moderately blood-contaminated with 101-3000 red blood cells per microliter, and severely bloodcontaminated with over 3000 red blood cells per microliter.

The neurological signs displayed by the patients were grouped into five main categories of localization: brain, vestibular, spinal cord, peripheral, and other. Designation of neurological signs for these groups was determined based on the highest level of neurological dysfunction demonstrated by the patient. Peripheral localization was allocated to those patients showing peripheral signs only: for example, facial nerve paralysis with no evidence of vestibular signs, mega-esophagus without dysphagia, radial nerve paralysis, etc. Spinal cord localization was designated in cases with ataxia, proprioceptive deficits, paralysis, and abnormal stance/ gait but without cranial nerve deficits, vestibular, or brain signs. Vestibular localization was designated if the patient had nystagmus and a head tilt in either the presence or absence of circling, leaning, or falling to one side. The distinction between peripheral or central vestibular disease was sometimes difficult based on the recorded abnormalities; however, if any brain signs were displayed in addition to the vestibular signs or if the nystagmus was vertical, then the localization was upgraded to brain. In this way, brain localization may include cases with central vestibular disease. Also, some animals showing only vestibular signs could have been peripheral or central vestibular in localization but categorized as vestibular for the purposes of this study. Localization to the brain category was made if the patient had seizure activity, cerebellar-origin head tremors, depression, dilated pupils, slow pupillary light reflexes (not of ophthalmic origin), cortical blindness, circling without a head tilt, or nystagmus in combination with any of the above-mentioned brain signs. Patients were categorized into the "other" localization category if the clinical signs demonstrated by the patient (including ataxia, weakness, and recumbency) could be explained by a non-neurological disease process: for example, hypothermia, orthopedic problems, or metabolic diseases. 
Patients were classed into one of nine disease categories: parasitic myelopathy, parasitic encephalopathy, trauma-associated, otitis, infectious, thermal, toxic, open neurological disease, or "other". Table 1 lists the type of disease included in each category.

\begin{tabular}{|c|c|}
\hline Disease Category & Diseases included within category listing \\
\hline Parasitic myelopathy & $\begin{array}{l}\text { Most likely to be infestation with } P \text { tenuis causing only spinal cord signs. } \\
\text { Compatible eosinophilia on CSF tap. Parasites and/or parasitic migration } \\
\text { tracts located only in spinal cord sections at necropsy. }\end{array}$ \\
\hline $\begin{array}{l}\text { Parasitic } \\
\text { encephalopathy }\end{array}$ & $\begin{array}{l}\text { Intracranial migration of parasites (most likely to be } P \text { tenuis) based on } \\
\text { necropsy findings or CSF tap combined with clinical findings. }\end{array}$ \\
\hline Trauma-associated & Spinal luxation/subluxations, spinal fractures, head/spinal trauma \\
\hline Otitis & Otitis interna/media/externa \\
\hline Infectious & $\begin{array}{l}\text { Meningitis, encephalitis, listeriosis, brain abscessation, septicemia, } \\
\text { hydrocephalus secondary to brain abscessation or meningitis, tetanus, } \\
\text { West Nile virus }\end{array}$ \\
\hline Thermal & Heat stress or hypothermia \\
\hline Toxic & $\begin{array}{l}\text { Rye grass toxicity, ionophore toxicosis, cerebral hypoxia, moxidectin } \\
\text { toxicity }\end{array}$ \\
\hline Open neuro & $\begin{array}{l}\text { Myelopathy, epilepsy, congenital spinal malformations, } \\
\text { polioencephalomalacia. Any disease with an unidentified but definite } \\
\text { neurologic cause. Disease does not fit into any other neurologic category. }\end{array}$ \\
\hline Other & $\begin{array}{c}\text { Any disease presenting with neurologic signs but attributable to a } \\
\text { non-neurologic cause Eg: hypomagnesemia, pregnancy toxemia, } \\
\text { hypoglycemia, or conditions that do not fit into another category, such as } \\
\text { musculoskeletal diseases and megaesophagus. }\end{array}$ \\
\hline
\end{tabular}

Table 1: Guide to categorization of neurological diseases within groups

\section{Statistical Analysis}

Data were analysed using a computer based statistical software program (SAS/STAT ${ }^{\circledR}$ Software, SAS Institute Inc, Cary, NC.) and summarized by calculating descriptive statistics and by presenting the data graphically where possible. For all statistical comparisons, a p-value of $<0.05$ was considered significant. The mean, median, standard deviation, and range were calculated for continuous variables, and these were then categorised in some cases to facilitate analysis. The frequency distributions of categorical variables were evaluated. Parasitic myelopathy/encephalopathy were compared with cases with different diagnoses to identify risk factors for disease (parasitic origin versus not parasitic).

All independent variables were screened initially to allow evaluation of simple associations with each of the outcome variables (parasitic versus not parasitic and whether the case was discharged or not) by calculating $\chi^{2}$ tests of homogeneity, as well as odds ratios and associated $95 \%$ confidence intervals. Variables meeting a critical a value of 0.25 following screening of bivariable associations were included when building multivariate models. Selection of variables for inclusion within the multivariate model utilised a forward-selection strategy. Development of the final multivariate model used a critical $\alpha$ value of 0.05 as a criterion to remain in the model. Odds ratios and their associated 95\% confidence intervals were estimated from the final logistic regression model.

\section{Results}

Computer search of medical records identified 185 individual case admissions presenting with neurological signs involving 181 camelids. One hundred and eighty-one individual patients were evaluated on 185 different occasions for unique neurological disease case admissions. A second occurrence of neurological disease occurred in 2 alpacas and 2 llamas. Of those animals, 1 alpaca was initially diagnosed with meningeal worm infestation, recovered and then was re-admited the next year because of ryegrass staggers; another alpaca suffered an undifferentiated neurological disease, recovered and was re-admitted the following year because of degenerative myelopathy; a llama was admitted initially because of spinal trauma, recovered, and was re-admitted 2 years later because of meningeal worm infestation; another llama was admitted for meningeal worm infestation, recovered, and was re-admitted 2 years later because of heat stress. A total of 185 occurrences were diagnosed and resulted in 90 alpacas and 95 llamas being entered into the database for analysis. Summary statistics for the continuous and categorical variables used in the analysis are displayed (Table 2 and 3). The species representation across the two main camelid species was similar with 90 alpaca (48.7\%) and 95 llama (51.4\%) individual case records reviewed. Gender distribution included 55.4\% females, 38.0\% males, and $6.5 \%$ castrated males. Age distribution is summarized (Table 3). It can be seen that $70.5 \%$ of cases were older than 12 months, $23.0 \%$ of cases were neonates and crias, and weanlings comprised $6.6 \%$ of cases. Among adults and juveniles, the most common diagnosis was parasitic myelopathy $(30.3 \%$ and $32.5 \%$, respectively). For neonates, the most frequent diagnosis was infectious disease $(50.0 \%$ ), with $64 \%$ of these involving meningitis or encephalitis. For crias aged 2-6 months, the most frequent diagnosis was trauma-related, accounting for $45.0 \%$ of cases. There was no single diagnosis that was more frequent for weanlings (aged 6-12 months). The majority of cases (30.7\%) were seen in the summer months (July to September); fewest cases (18.52\%) were seen in 
spring (April to June). Confirmation of a diagnosis was achieved, either by positive CSF, radiographic, or laboratory or necropsy findings in $74.0 \%$ of cases. $54.4 \%$ of cases were discharged from the hospital; the remainder either died or were euthanized.

\begin{tabular}{|c|c|c|c|c|}
\hline Variable & $\begin{array}{c}\text { Animals } \\
\text { (n) }\end{array}$ & $\begin{array}{c}\text { Mean + } \\
\text { standard } \\
\text { deviation }\end{array}$ & Median & Range \\
\hline \multicolumn{5}{|l|}{ CSF } \\
\hline Protein (mg/dl) & 137 & $109 \pm 233$ & 62 & $0.54-2530$ \\
\hline Creatine kinase (IU/L) & 112 & $472 \pm 1929$ & 17 & $0-17559$ \\
\hline Neutrophils \% & 137 & $21 \pm 29$ & 4 & $0-97$ \\
\hline Monocytes \% & 138 & $29 \pm 27$ & 20 & $0-100$ \\
\hline Lymphocytes \% & 137 & $29 \pm 28$ & 18 & $0-100$ \\
\hline Eosinophils \% & 138 & $21 \pm 33$ & 0 & $0-99$ \\
\hline Basophils \% & 137 & $0.1 \pm 0.5$ & 0 & $0-5$ \\
\hline Mast cells \% & 137 & $0.0 \pm 0.2$ & 0 & $0-2$ \\
\hline Total red blood cells / $\mu \mathrm{l}$ & 139 & $15042 \pm 50874$ & 141 & $0-360000$ \\
\hline Total white blood cells $/ \mu \mathrm{l}$ & 139 & $300 \pm 1926$ & 6 & $0-21600$ \\
\hline \multicolumn{5}{|l|}{ СBC } \\
\hline Total WBCC (cells x109/L) & 112 & $17 \pm 8$ & 15 & $5-53$ \\
\hline Segmented neutrophils \% & 112 & $78 \pm 12$ & 80 & $24-94$ \\
\hline Band neutrophils \% & 112 & $3 \pm 6$ & 1 & $0-31$ \\
\hline Lymphocytes \% & 112 & $13 \pm 10$ & 11 & $0-66$ \\
\hline Monocytes \% & 112 & $3 \pm 2$ & 3 & $0-12$ \\
\hline Eosinophils \% & 112 & $3 \pm 3.6$ & 2 & $0-17$ \\
\hline Basophils \% & 111 & $0.2 \pm 0.5$ & 0.0 & $0-2$ \\
\hline Serum Creatine Kinase (IU/L) & 52 & $14335 \pm 43819$ & 1525 & $31-216760$ \\
\hline Age (years) & 183 & $3 \pm 3$ & 3 & $0.0-20$ \\
\hline
\end{tabular}

Table 2: Summary statistics for the continuous variables. Data was not available for all cases. The number of animals included in each data set are provided by " $\mathrm{n}$ "

\begin{tabular}{|c|c|c|c|}
\hline Variable & Category & $\begin{array}{l}\text { Number in } \\
\text { each category }\end{array}$ & $\begin{array}{l}\text { \% within } \\
\text { category }\end{array}$ \\
\hline Age & $\begin{array}{l}\text { Neonate ( }<2 \text { months) } \\
\text { Cria (2-6 months) } \\
\text { Weanling (6-12 months) } \\
\text { Juvenile ( } 1-2 \text { years) } \\
\text { Adult ( }>2 \text { years })\end{array}$ & $\begin{array}{l}22 \\
20 \\
12 \\
40 \\
89\end{array}$ & $\begin{array}{c}12 . \\
11 \\
6 \\
22 \\
49\end{array}$ \\
\hline Month & $\begin{array}{c}\text { January } \\
\text { February } \\
\text { March } \\
\text { April } \\
\text { May } \\
\text { June } \\
\text { July } \\
\text { August } \\
\text { September } \\
\text { October } \\
\text { November } \\
\text { December }\end{array}$ & $\begin{array}{c}6 \\
20 \\
17 \\
10 \\
13 \\
10 \\
22 \\
24 \\
12 \\
21 \\
18 \\
16\end{array}$ & $\begin{array}{c}3 \\
11 \\
9 \\
5 \\
7 \\
5 \\
12 \\
13 \\
6 \\
11 \\
10 \\
8\end{array}$ \\
\hline Season & $\begin{array}{l}\text { Spring (April to June) } \\
\text { Summer (July to September) } \\
\text { Fall (October to December) } \\
\text { Winter (January to March) }\end{array}$ & $\begin{array}{l}35 \\
58 \\
54 \\
42\end{array}$ & $\begin{array}{l}18 \\
31 \\
28 \\
22\end{array}$ \\
\hline Gender & $\begin{array}{c}\text { Male } \\
\text { Female } \\
\text { Gelding }\end{array}$ & $\begin{array}{c}70 \\
102 \\
12\end{array}$ & $\begin{array}{c}38 \\
55 \\
7\end{array}$ \\
\hline Species & $\begin{array}{l}\text { Alpaca } \\
\text { Llama }\end{array}$ & $\begin{array}{l}90 \\
95\end{array}$ & $\begin{array}{l}49 \\
51\end{array}$ \\
\hline
\end{tabular}




\begin{tabular}{|c|c|c|c|}
\hline Variable & Category & $\begin{array}{l}\text { Number in } \\
\text { each category }\end{array}$ & $\begin{array}{l}\text { \% within } \\
\text { category }\end{array}$ \\
\hline Extension District (Ohio) & $\begin{array}{c}\text { North } \\
\text { South } \\
\text { East } \\
\text { West } \\
\text { Out of State }\end{array}$ & $\begin{array}{l}54 \\
15 \\
48 \\
19 \\
49\end{array}$ & $\begin{array}{l}40 \\
11 \\
35 \\
14\end{array}$ \\
\hline $\begin{array}{c}\text { Localisation of Neurological } \\
\text { Signs }\end{array}$ & $\begin{array}{l}\text { Central } \\
\text { Vestibular } \\
\text { Spinal Cord } \\
\text { Peripheral } \\
\text { Other }\end{array}$ & $\begin{array}{c}58 \\
20 \\
84 \\
8 \\
15\end{array}$ & $\begin{array}{c}31 \\
11 \\
45 \\
4 \\
8\end{array}$ \\
\hline CSF Tap Results Available? & $\begin{array}{l}\text { Yes } \\
\text { No }\end{array}$ & $\begin{array}{c}140 \\
47\end{array}$ & $\begin{array}{l}75 \\
25\end{array}$ \\
\hline $\begin{array}{l}\text { CBC results within } 1 \text { day of } \\
\text { CSF tap available? (as a \% of } \\
\text { total CSFs) }\end{array}$ & $\begin{array}{l}\text { Same day } \\
-1 \text { day } \\
+1 \text { day }\end{array}$ & $\begin{array}{c}79 \\
29 \\
4 \\
\end{array}$ & $\begin{array}{c}70 \\
26 \\
4 \\
\end{array}$ \\
\hline CSF Protein & $\begin{array}{c}\text { Normal }(\leq 50 \mathrm{mg} / \mathrm{dl}) \\
\text { Mild/moderate increase }(51-100 \\
\mathrm{mg} / \mathrm{dl}) \\
\text { Severe increase }(>100 \mathrm{mg} / \mathrm{dl})\end{array}$ & $\begin{array}{l}56 \\
43 \\
38\end{array}$ & $\begin{array}{l}41 \\
31 \\
28\end{array}$ \\
\hline CSF CK & $\begin{array}{l}\text { Normal ( } \leq 15 \mathrm{IU} / \mathrm{L}) \\
\text { Increased }(>15 \mathrm{IU} / \mathrm{L})\end{array}$ & $\begin{array}{l}54 \\
58\end{array}$ & $\begin{array}{l}48 \\
52\end{array}$ \\
\hline CSF Eosinophils & $\begin{array}{c}\text { Normal }(0 \%) \\
\text { Mild increase }(1-9 \%) \\
\text { Moderate increase }(10-69 \%) \\
\text { Severe increase }(\geq 70 \%)\end{array}$ & $\begin{array}{l}69 \\
24 \\
21 \\
22\end{array}$ & $\begin{array}{l}51 \\
18 \\
15 \\
16\end{array}$ \\
\hline CSF RBC count & $\begin{array}{c}\text { Clean tap }(0-100 \mathrm{rbcs} / \mu \mathrm{l}) \\
\text { Mild blood contamination }(101 \\
-3000 \mathrm{rbcs} / \mu \mathrm{l}) \\
\text { Severe blood contamination } \\
\quad(>3000 \mathrm{rbcs} / \mu \mathrm{l})\end{array}$ & $\begin{array}{l}66 \\
33 \\
38\end{array}$ & $\begin{array}{l}48 \\
24 \\
28\end{array}$ \\
\hline Diagnosis confirmed & $\begin{array}{l}\text { Yes } \\
\text { No }\end{array}$ & $\begin{array}{c}131 \\
46\end{array}$ & $\begin{array}{l}74 \\
26\end{array}$ \\
\hline Discharge Status & $\begin{array}{c}\text { Discharged } \\
\text { Died/euthanased }\end{array}$ & $\begin{array}{c}100 \\
84\end{array}$ & $\begin{array}{l}54 \\
46\end{array}$ \\
\hline Disease Category & $\begin{array}{c}\text { Parasitic myelopathy } \\
\text { Parasitic encephalopathy } \\
\text { Trauma-associated } \\
\text { Otitis } \\
\text { Infectious } \\
\text { Thermoregulatory } \\
\text { Toxic } \\
\text { Open Neuro } \\
\text { Other }\end{array}$ & $\begin{array}{l}43 \\
14 \\
22 \\
12 \\
27 \\
10 \\
14 \\
23 \\
20\end{array}$ & $\begin{array}{c}23 \\
8 \\
12 \\
6 \\
15 \\
5 \\
8 \\
12 \\
11\end{array}$ \\
\hline Meningeal worm & $\begin{array}{l}\text { Yes } \\
\text { No }\end{array}$ & $\begin{array}{c}58 \\
127\end{array}$ & $\begin{array}{l}31 \\
69\end{array}$ \\
\hline Year of Admission & $\begin{array}{l}1993 \\
1995 \\
1996 \\
1997 \\
1998 \\
1999 \\
2000 \\
2001 \\
2002 \\
2003\end{array}$ & $\begin{array}{c}1 \\
4 \\
9 \\
4 \\
31 \\
26 \\
32 \\
31 \\
20 \\
31\end{array}$ & $\begin{array}{c}0.5 \\
2 \\
5 \\
2 \\
16 \\
14 \\
17 \\
16 \\
11 \\
16\end{array}$ \\
\hline
\end{tabular}

Table 3: Summary statistics for the independent categorical variables

Of the 181 llamas and alpaca cases, 136 animals resided within Ohio. Ohio cases were divided into counties and into North, South, East, and West extension districts to determine a possible geographic bias based on disease type found in those areas (Figure 1). Within Ohio, the Eastern extension district had significantly more animals diagnosed with PME compared with all other districts $(\mathrm{p}<0.05)$.

A variety of neurologic diseases were identified (Figure 2). Of those, the largest percentage of cases (30.8\%) was classified as either parasitic myelopathy or parasitic encephalopathy. Age was a factor in the multiple logistic regression models, since it is often a 


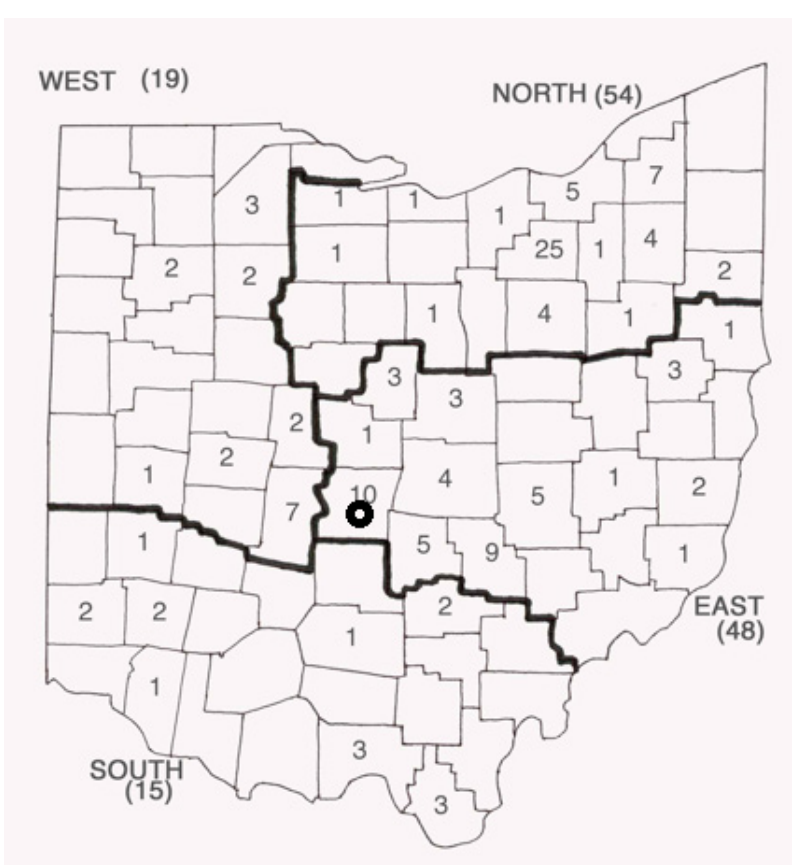

Figure 1: Map of Ohio showing case distribution by county. The Veterinary Teaching Hospital is located centrally (open black circle) and extension districts are demarcated by the thick black lines. Total cases in each county are enumerated and in each extension district are in parentheses

confounding variable in these disease conditions. Overall, age had a significant influence on whether the animal was likely to have PME based on the likelihood ratio for type 3 analysis $(p<0.05)$. However, it was hard to distinguish the relative risk of an animal in each age category developing PME due to other confounding variables. Although not statistically significant in the overall model, adults were 25 times more likely to have PME than juveniles ( $\mathrm{p}=0.0892)$. There was a significant effect of season on the distribution of PME cases $(\mathrm{p}<0.05)$. Fall and winter months (October to March) were the highest risk periods for developing clinical signs of PME (Figure 3). There was no significant difference between the risk of developing PME in either winter or fall.

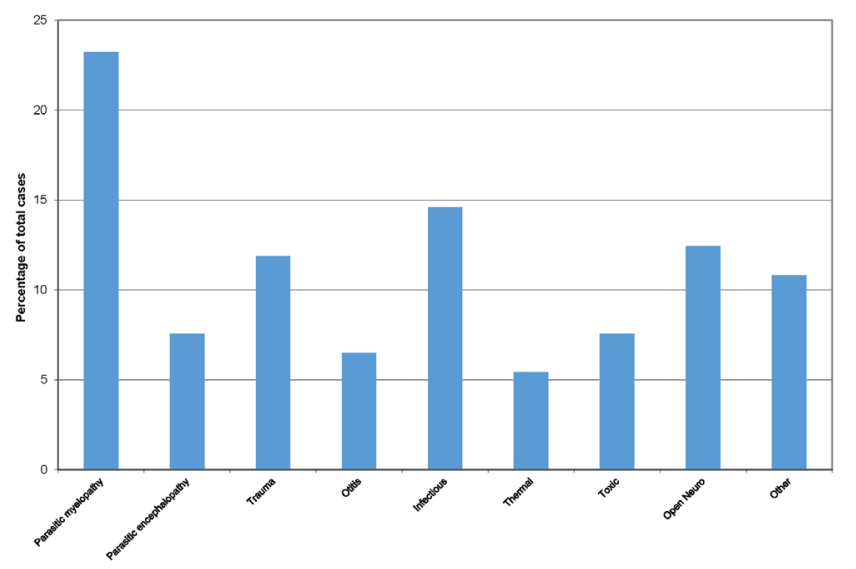

Figure 2: Frequency histogram of clinical diagnosis for neurologic disease affecting camelids in this case study. P myelopathy = parasitic myelopathy. $\mathrm{P}$ encephalopathy = parasitic encephalopathy

Cerebrospinal fluid was obtained in a total of 140 case admissions (Table 2 and 3). All except one of the CSF samples were taken from the lumbosacral space. $51.8 \%$ of CSF samples in which CK was measured $(n=112)$ had an increased CK concentration $(>15$ IU/L). $59.1 \%$ of samples had an increased protein concentration, with $31.4 \%$ having $\mathrm{mild} / \mathrm{moderate}$ increase and $27.7 \%$ having severe increase $(>100 \mathrm{mg} / \mathrm{dl})$. All but two of the 43 cases with moderate or severe CSF eosinophilia were PME cases, and, of these, only one was not considered confirmed. $48.2 \%$ of CSF taps were considered clean; $24.1 \%$ of taps were mildly or moderately bloodcontaminated, and $27.7 \%$ were severely blood-contaminated. 


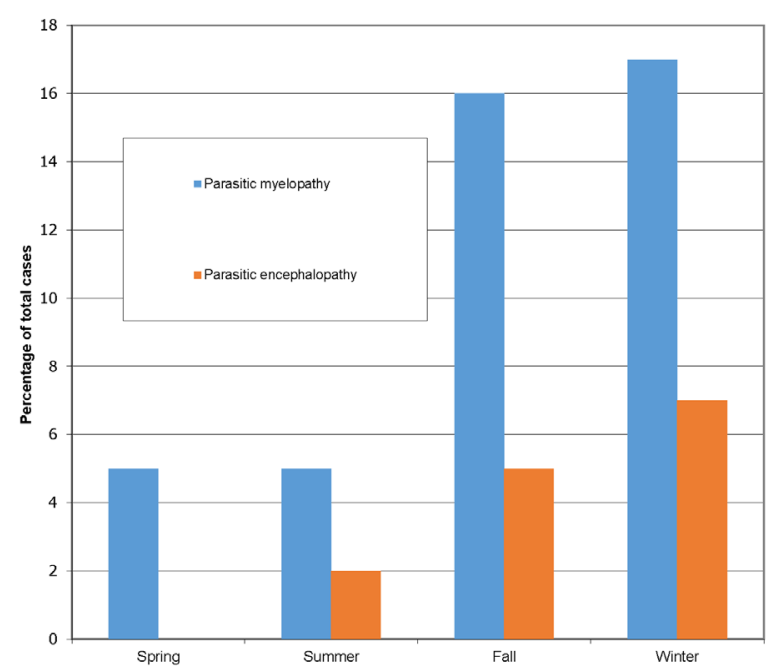

Figure 3: Percentage histogram representing the seasonal distribution of parasitic myelopathy/encephalopathy (meningeal worm) cases included in this case study

The concentration of protein in the CSF was significant with regard to a diagnosis of PME ( $<<0.05$ ). An animal having severely increased CSF protein was 63 times more likely to be diagnosed with PME than if the protein concentration was normal ( $p<$ 0.05). However, the influence of protein concentration was no longer significant once confounding variables were considered in the overall model. CSF protein was increased in $73.3 \%$ of PME cases included in this study. Surprisingly, 58.3\% of trauma-related cases had normal CSF protein. Eosinophilia was significant with regard to whether or not an animal was diagnosed with PME ( $\mathrm{p}<$ 0.05), but this was unstable in the overall model (Figure 4). In this study, $85.4 \%$ of parasitic myelopathy cases had either moderate or severe CSF eosinophilia compared with only $54.5 \%$ in parasitic encephalopathy cases. Increasing percentages of lymphocytes and monocytes in CSF cytology reduced the overall chance of a PME diagnosis ( $p<0.05$ and $\mathrm{p}<0.05$ respectively) once the effect of confounding variables were taken into consideration. There was no significant difference in CSF CK concentration (either with respect to the continuous or categorical variables) between animals diagnosed with PME or something else. Neither was CSF CK significant with regard to discharge status. When only clean taps are considered, again there was no apparent disease association with an increase in CSF CK. The CSF findings for each of the main differential diagnoses are shown (Table 4).

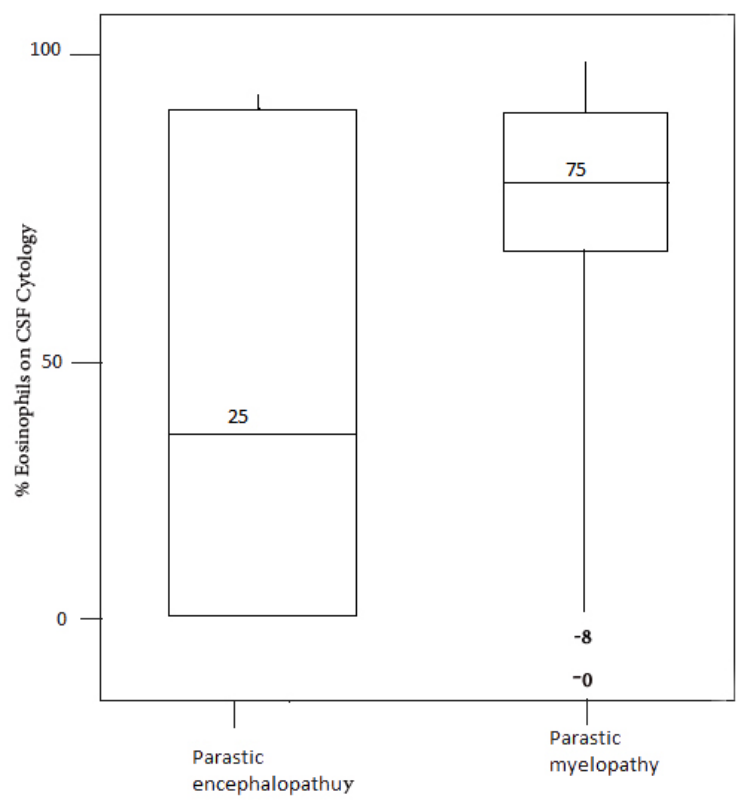

Figure 4: Graphical presentations of the eosinophil percentage in CSF cytology for parasitic myelopathy and parasitic encephalopathy cases showing the median and range for these categories 


\begin{tabular}{|c|c|c|c|c|c|c|}
\hline Diagnosis & $\begin{array}{c}\text { Protein }(\mathbf{m g} / \\
\mathbf{d l})\end{array}$ & CK (IU/L) & Eos (\%) & Monos (\%) & Lymphs (\%) & Neuts (\%) \\
\hline Parasitic Myelopathy $(\mathrm{n}=31)$ & $111(31-279)$ & $165(0-1236)$ & $67(0-99)$ & $16.1(1-56)$ & $14.1(0-85)$ & $2.6(0-25)$ \\
\hline $\begin{array}{c}\text { Parasitic Encephalopathy } \\
(\mathrm{n}=9)\end{array}$ & $83(24-168)$ & $19(1-83)$ & $42(0-92)$ & $30.4(3-78)$ & $23.9(0-75)$ & $5.5(0-18)$ \\
\hline Trauma (n=10) & $80(0.54-376)$ & $103(0-445)$ & $0.5(0-5)$ & $42(1-100)$ & $38.3(0-91)$ & $19.2(0-94)$ \\
\hline Otitis (n=6) & $52(18-97)$ & $32(3-91)$ & $0.8(0-5)$ & $21.8(3-65)$ & $50.2(8-82)$ & $27.2(0-89)$ \\
\hline Listeriosis (n=3) & $64(46-78)$ & $25(0-69)$ & $0.3(0-1)$ & $39.3(17-62)$ & $46.7(20-83)$ & $13.7(0-40)$ \\
\hline Meningitis/Encephalitis $(\mathrm{n}=3)$ & $78(49-125)$ & $15(3-24)$ & 0 & $25.3(13-43)$ & $46.3(1-81)$ & $28.0(0-55)$ \\
\hline Brain Abscess (n=1) & 80 & - & 0 & 38 & 49 \\
\hline Heat stress $(\mathrm{n}=7)$ & $35(17-86)$ & $50(1-251)$ & 0 & $39.5(12-80)$ & $47.0(20-86)$ & $13.5(0-55)$ \\
\hline Rye Grass Staggers (n=4) & $43(20-77)$ & $521(3-1541)$ & $0.5(0-2)$ & $52.0(20-65)$ & $41.3(33-57)$ & $6.0(0-21)$ \\
\hline
\end{tabular}

Table 4: Table showing CSF findings (means and ranges) for each of the major differential diagnoses of neurological disease in llamas and alpacas. CSF results are only included where there were less than 3000 red blood cells

The distribution of cases for localization of neurological signs is shown (Table 3). 71.9\% of PME cases had spinal cord signs only; $28.1 \%$ of PME cases showed intracranial involvement (brain and vestibular localization) in this study. In this study, the highest frequency of brain localization was made in cases with either an infectious (34.5\%) or toxic etiology (22.4\%). The highest frequency of vestibular signs was observed in cases of otitis interna/media (45\%), parasitic encephalopathy (25\%), or other infectious causes (10\%). Spinal cord signs were observed most frequently in cases of meningeal worm (48.8\%) or cases with a traumatic etiology (20.2\%). Additionally, $16.7 \%$ of neurological cases with an unidentified or miscellaneous cause, such as polioencephalomalacia, displayed spinal cord signs. Peripheral localization of signs was seen only in musculoskeletal conditions such as radial nerve paralysis, mega-esophagus, and otitis.

Gender was not a significant factor with regard to the diagnosis. However, there was a species effect identified in that llamas in the present study were nearly 12 times more likely to be diagnosed with PME than alpacas $(\mathrm{p}<0.05)$. This difference became insignificant when confounding variables were taken into consideration.

With respect to whether or not an animal was discharged, disease category was the most important factor $(\mathrm{p}<0.05)$, but there was little significant difference between disease categories due to other confounding variables. The only significant difference was that cases diagnosed with parasitic encephalopathy were very unlikely to be discharged $(\mathrm{p}<0.05)$. Only $7 \%$ of parasitic encephalopathy cases were discharged compared with $77 \%$ of parasitic myelopathy cases (Table 5). The best success was seen with heat stress, where $88 \%$ of cases were discharged. The worst overall category discharge rate was seen in the infectious diseases category (26\%). Additionally, the age of the animal was also significant; for every one year increase in age, there was 1.6 times less chance of being discharged $(\mathrm{p}<0.05)$. The degree of eosinophilia in the CSF was also significant to the model with respect to discharge status $(\mathrm{p}<$ 0.05) (Table 6). If a patient had 0\% eosinophils or mild eosinophilia (up to 9\%) in the CSF, it was much less likely to be discharged than if there were $70-100 \%$ eosinophils. Finding no or minimal eosinophilic pleocytosis supported a diagnosis other than PME or a blood-contaminated tap. There was no significant difference in discharge rate between a moderate and severe eosinophilia.

\begin{tabular}{|c|c|c|c|c|c|}
\hline Variable & Estimate & $\begin{array}{l}\text { Odds } \\
\text { Ratio }\end{array}$ & $\begin{array}{c}95 \% \\
\text { Confidence } \\
\text { Interval }\end{array}$ & p-value & $\begin{array}{c}\text { Overall } \\
\text { p-value } \\
\text { (type } 3 \\
\text { analysis) }\end{array}$ \\
\hline $\begin{array}{l}\text { Age } \\
\text { Neonate } \\
\text { Cria } \\
\text { Weanling } \\
\text { Juvenile } \\
\text { Adult }\end{array}$ & $\begin{array}{c}-26.53 \\
-1.92 \\
-1.10 \\
-1.39 \\
\text { Reference }\end{array}$ & $\begin{array}{l}0.00 \\
0.01 \\
0.08 \\
0.04\end{array}$ & $0.00-1.64$ & $\begin{array}{l}\text { ns } \\
\text { ns } \\
\text { ns } \\
\text { ns }\end{array}$ & $<0.05$ \\
\hline $\begin{array}{l}\text { Season } \\
\text { Fall } \\
\text { Spring } \\
\text { Summer } \\
\text { Winter }\end{array}$ & $\begin{array}{c}-0.23 \\
-4.29 \\
-3.53 \\
\text { Reference }\end{array}$ & $\begin{array}{l}0.59 \\
0.00 \\
0.00\end{array}$ & $\begin{array}{l}0.000-0.06 \\
0.000-0.07\end{array}$ & $\begin{array}{c}\text { ns } \\
<0.05 \\
<0.05\end{array}$ & $<0.05$ \\
\hline \% Lymphocytes in CSF & -0.04 & 0.91 & $0.85-0.97$ & $<0.05$ & $<0.05$ \\
\hline \% Monocytes in CSF & -0.03 & 0.94 & $0.88-1.00$ & $<0.05$ & $<0.05$ \\
\hline $\begin{array}{l}\text { Extension District } \\
\text { (Ohio) } \\
\text { North } \\
\text { East } \\
\text { South } \\
\text { West }\end{array}$ & $\begin{array}{c}2.26 \\
3.85 \\
2.44 \\
\text { Reference }\end{array}$ & $\begin{array}{c}182.10 \\
7110.50 \\
276.06\end{array}$ & $\begin{array}{c}0.17-177869 \\
5.19-10493008 \\
0.17-418697\end{array}$ & $\begin{array}{c}0.14 \\
0.017 \\
0.13\end{array}$ & $<0.05$ \\
\hline
\end{tabular}

Table 5: Final multiple logistic regression model for factors affecting whether or not an animal was diagnosed with parasitic myelopathy/encephalopathy (meningeal worm) 


\begin{tabular}{|c|c|c|c|c|c|}
\hline Variable & Estimate & Odds Ratio & $\begin{array}{l}\text { 95\% Confidence } \\
\text { Interval }\end{array}$ & p-value & $\begin{array}{l}\text { Overall } \\
\text { p-value } \\
\text { (type } 3 \\
\text { analysis) }\end{array}$ \\
\hline $\begin{array}{l}\text { Disease Category } \\
\text { Parasitic myelopathy } \\
\text { Parasitic } \\
\text { Encephalopathy } \\
\text { Trauma-associated } \\
\text { Otitis } \\
\text { Infectious } \\
\text { Thermoregulatory } \\
\text { Toxic } \\
\text { Open neuro } \\
\text { Other }\end{array}$ & $\begin{array}{c}0.10 \\
4.11 \\
\\
0.43 \\
-2.26 \\
0.89 \\
-25.53 \\
-0.37 \\
-1.07 \\
\text { Reference }\end{array}$ & $\begin{array}{c}1.26 \\
12871 \\
\\
2.72 \\
0.005 \\
7.78 \\
2.96 \times 10^{-26} \\
0.43 \\
0.08\end{array}$ & $\begin{array}{c}0.008-210.96 \\
6.952-23823194 \\
0.045-165.35 \\
0.000-1.94 \\
0.176-344.35 \\
0- \\
0.006-31.09 \\
0.002-4.90\end{array}$ & $\begin{array}{c}\text { ns } \\
<0.05 \\
\text { ns } \\
\text { ns } \\
\text { ns } \\
\text { ns } \\
\text { ns } \\
\text { ns }\end{array}$ & $<0.05$ \\
\hline Age (years) & 0.2 & 1.58 & $1.07-2.34$ & 0.021 & 0.016 \\
\hline $\begin{array}{l}\text { Eosinophils in CSF } \\
\text { Normal: } 0 \% \\
\text { Mild elevation: } 1-9 \% \\
\text { Moderate elevation: } 10-69 \% \\
\text { Severe elevation: } \geq 70 \%\end{array}$ & $\begin{array}{c}2.36 \\
3.23 \\
0.91 \\
\text { Reference }\end{array}$ & $\begin{array}{c}230.20 \\
1695.12 \\
8.04\end{array}$ & $\begin{array}{c}1.02-51904 \\
7.98-360247 \\
0.12-526.7\end{array}$ & $\begin{array}{c}0.049 \\
0.007 \\
0.33\end{array}$ & 0.02 \\
\hline
\end{tabular}

Table 6: Multiple logistic regression model for factors affecting discharge status

There were 58 total PME cases. Of the 58 cases, 35 survived, 4 died, and 19 were euthanized.

There were 22 trauma cases represented in the current study; $45 \%$ of which were discharged from the hospital. These included 12 cervical spine problems, 7 cases of thoracolumbar spinal trauma, and 3 head trauma cases. Analysis of CSF was performed in 12 cases and was found to be normal in 5 cases. Increased protein $(n=5$ out of 12$)$ and CK $(n=5$ out of 8$)$ was found in some cases and the cytology was typically normal.

Eleven cases of otitis media/interna were included in the current study, 7 of which were discharged from the hospital. Where CSF analysis was done $(n=6)$, protein concentrations were normal in 3 and increased in 3 . Creatine kinase was increased in 2 of 4 samples in which it was measured, and these were clean taps. Increased white blood cell count was found in 3 out of 6 CSF samples, and cytology showed neutrophilic or suppurative inflammation in these cases. Further diagnostic procedures included bulla radiographs, CT, and brainstem auditory evoked response test.

In the infectious category, cerebrospinal fluid findings were variable with increased protein concentration the most consistent feature. There were 3 brain abscess cases and 5 cases of listeriosis; 4 of which were confirmed at necropsy by demonstration of characteristic lesions affecting particularly the brainstem. Cytology of the CSF showed monocytosis in 3/5 cases.

Nine cases of meningitis or encephalitis were identified (3 llamas, 6 alpacas), and 7 were in animals less than one month old. Two animals were discharged from the hospital. In 6 cases CSF analysis was performed. The CSF in these cases showed mixed or suppurative inflammation, commonly with increased protein concentrations. Septicemia caused neurological signs in 5 neonates and crias. Two llamas were diagnosed with tetanus based on clinical signs. Two cases of West Nile Viral encephalitis were identified in the current study; both were alpacas and had positive West Nile Virus titres in CSF and immunohistochemistry of brain tissue.

Eight cases of heat stress and two cases of hypothermia were included in the current study, and all cases were llamas. CSF analysis was performed in 7 cases and was normal except in one animal with a mild/moderate increase in protein concentration (the worst affected animal). Cytology of the CSF was normal in all samples.

Fourteen cases presented with neurological signs following a toxic insult. This group included 5 alpacas that had ingested salinomycin-contaminated feed, 7 alpacas with ryegrass staggers, one alpaca diagnosed with moxidectin toxicity, and one neonatal llama with cerebral hypoxia. The salinomycin and moxidectin intoxicated alpacas all died, whereas all animals with ryegrass staggers and cerebral hypoxia were discharged. Four out of five of the salinomycin cases had CSF analysis performed, and this was normal other than markedly increased CK concentration in 3 cases (117 - $828 \mathrm{IU} / \mathrm{L})$. These animals all had severe increases of serum CK, ranging from 137,070 - 216,760 IU/L but little blood contamination of the CSF (3, 5 and 156 red blood cells per $\mu \mathrm{L})$.

The 7 alpacas diagnosed with ryegrass staggers were all discharged. Presenting neurological signs in these animals included head and/or neck tremors, ataxia, and hypersalivation. Diagnosis in these cases was based on compatible clinical signs and a normal CSF tap in 6/7 cases.

Three cases of mega-esophagus were identified in the current study. Animals were aged 2-5 years at the time of presentation and included 2 llamas and 1 alpaca. Mega-esophagus was diagnosed based on thoracic radiographs and, in one case, with a barium esophagram. Further diagnostic testing in these cases included serum mineral analysis, tensilon test, serum acetylcholinesterase antibody assay, and thyroid panel. All tests were normal. It is unknown whether the acetylcholinesterase antibody test is valid in camelids. Also in the "other" category were 7 case admissions found to be exhibiting neurologic signs due to metabolic causes, including hepatic encephalopathy, "pregnancy toxemia," hypomagnesemia, hypoglycemia, and hyperglycemia. 


\section{Discussion}

The present study represents the largest retrospective study of neurological disease in llamas and alpacas. Many clinicians dealing with these species in the field are familiar with "Meningeal Worm" and will often treat for this disease [14,18]. The results of this study show that other differentials should be considered when formulating treatment plans. Parasitic encephalopathy should be considered a differential for animals showing intracranial neurological signs, since not all cases will show the classic spinal cord neurological signs typically associated with this disease. In the cases in this study, a diagnosis of PME was made based on CSF eosinophilia with compatible clinical signs if the animal survived or on finding characteristic histopathologic lesions within the CNS following necropsy. Actual larvae were found in 5 out of 22 cases, and these are assumed to be P. tenuis. Although no other nematode parasites have been implicated in causing neurological disease in camelids, attempts to specifically identify nematode species in these cases were not made. Recently, a nested PCR test has been reported for use in camelids [22]. This may offer clinicians a more specific test for the diagnosis of Parelaphostrongylus species infestations.

In this study, PME was significantly more common in adult animals than in younger ones and was the most common diagnosis among juveniles. The youngest case affected in our study was 5 months old. The significance of the effect of season is important since fall and winter months (October through to March) carry the highest risk for a diagnosis of PME, while spring and summer carry the lowest risk.

The geographic bias for cases from within Ohio is interesting. There was a significantly higher risk of a particular animal with neurological disease being diagnosed with PME if it came from the Eastern extension district $(\mathrm{p}<0.05)$. This was true even when confounding variables were taken into consideration. The counties included in this district are hilly and forested, making them excellent territory for white tailed deer, the definitive host of $P$. tenuis, and the intermediate mollusc hosts.

Disease category was the most important single factor affecting whether or not an animal was discharged. However, it was not possible to detect significant differences in the likelihood of discharge between the disease categories due to the effect of confounding variables and low cell numbers. This may also have been affected by putting different diseases into overall groups (e.g. listeriosis, meningitis, and septicemia grouped together under infectious disease). The only significant difference was concerning animals with parasitic encephalopathy, being very unlikely to be discharged compared to animals with any other neurological disease. The markedly better discharge rate for parasitic myelopathy (77\%) as compared with encephalopathy (7\%) strongly suggests that when intracranial involvement is established the prognosis is considerably worse. Since the finding of CSF eosinophilia in parasitic encephalopathy is not as likely, this cannot be used to rule out parasitic involvement in these cases.

In this study, the best discharge success was for heat stress cases. This contrasts with experience in Alabama [23]. In Alabama, a state in the southern region of the United States, a greater percentage of recumbent camelids were diagnosed with heat stress, and almost $50 \%$ of those died or were euthanized. The difference in success rate is probably due to a greater number and severity of hot and humid days in Alabama as compared to Ohio. In addition, in this study, survivors were treated relatively early in the clinical stages of the disease (within 1-2 days of onset of clinical signs).

Increases in both CSF protein and the proportion of eosinophils on cytology were significant in terms of diagnosing PME, although it was not possible to see the overall effect of eosinophilia in the model when confounding variables were taken into consideration due to instability in the model. The reason why fewer cases of parasitic encephalopathy as compared to myelopathy were diagnosed on CSF is unclear. A possible reason is that the lumbosacral site is remote from the brain, and an atlanto-occipital sample might yield more results that are positive. However, in only one of the cases with parasitic encephalopathy in this study were lesions present in the brain but not elsewhere in the CNS. A recent study focused on the diagnostic sensitivity and specificity of CSF analysis for the clinical diagnosis of Parelaphostrongylus tenuis infestation [24]. In that study, the authors reported that CSF having $>17 \%$ eosinophils had a sensitivity of $85 \%$ and specificity of $92 \%$ for $P$. tenuis and when eosinophils concentration was $>1.4$ eosinophils/uL that the sensitivity was $85 \%$ and specificity was $96 \%$.

CSF analysis was useful in identifying other neurological diseases, especially otitis, meningitis, and spinal trauma, but findings in listeriosis cases were disappointingly inconsistent, with a clear monocytosis only being observed in $2 / 5$ cases. Our study agrees with others in finding that CSF CK is not particularly useful in differentiating neurological diseases [25].

Crias less than 30 days old are especially susceptible to disease related to failure of passive transfer of immunity resulting from inadequate colostrum ingestion [1-6]. In addition, the crias diagnosed with brain abscesses were diagnosed at 1, 5, and 8 months of age, and it is likely that the same risk factors were involved in these cases. Crias with meningitis show remarkably variable and vague clinical signs. In some cases, the only clinical sign on presentation was abdominal discomfort, and this progressed to signs of CNS depression within several days. Our data show that meningitis cases have a good chance of a CSF tap revealing leukocytosis on cytology. None of the animals reported in the literature as having meningitis or encephalitis survived [1-6]. This fact and the fact that the cases represented in this study had a $22 \%$ survival rate suggest that cases developing meningitis/encephalitis have a grave prognosis even with aggressive treatment. Similarly, listeriosis cases had a very poor outcome in the cases included in this study with only a $20 \%$ discharge rate.

Ryegrass staggers was diagnosed in 7 cases in the present series and was based on clinical signs of head and neck tremors and resolution of signs following removal of the animals from pasture. These clinical findings have been reported previously in alpacas 
in the UK [7]. In some cases, clinical signs returned after re-introduction to the same pasture. Pasture was tested on a few farms for lolitrem B toxin, and concentrations were highly variable. For most of the toxins that cause grass staggers, diagnostic tests are available but are most useful following identification of the grass species in pasture in order to guide toxin testing: for example, lolitrems in perennial ryegrass, corynetoxin in annual ryegrass, and tryptamine alkaloids in Canary grass.

Few cases of spinal trauma have been reported in the literature other than anecdotal reports [8]. The majority of traumatic events in llamas and alpacas in this study involved cervical vertebral luxations and subluxations. Trauma was the most frequent diagnosis in crias of the 2-6 month age range; this age of animal seems more likely to be startled and run into inanimate objects. The prognosis is relatively good for cervical spinal injuries due to the width of the spinal canal in this region, as long as the defect is not too severe in a growing animal.

Computed tomography was useful for diagnosing brain abscesses, head trauma, and otitis interna. Bone sequestra occur frequently in severe otitis media, and CT highlights these clearly. Due to the inability to properly inspect the entire external ear canal and the tympanic membrane using an otoscope in camelids, it is very difficult to know how extensive infection has become without this tool $[5,26,27]$. It is noteworthy that very few cases represented in this series had any obvious discharge or debris in the external ear canal. This suggests that most otitis interna/media occurs as an extension of respiratory disease from organisms tracking up the Eustachian tubes into the inner ear.

Viral encephalitis appears to be quite rare. In the current case series, there was one cria diagnosed with herpesvirus infection, and two cases of West Nile Virus infection are included. West Nile Virus infection has previously been reported in alpacas [9-11]. Other viruses have been implicated in neurological disease in camelids, including an outbreak of blindness and encephalitis in a herd of alpacas and llamas that was associated with EHV-1 [12], and four llamas with pneumonia and hepatitis also showed vague neurologic deficiencies associated with adenovirus infection [28]. Neurological signs have been reproduced experimentally with EHV-1 in llamas; 2 out of 3 infected llamas developed severe signs within one week of infection [29]. EHV-1 should be regarded as a differential diagnosis for neurological disease in camelids, especially if the affected animals have been kept in close proximity to horses. More recently, Eastern Equine Encephalitis has been reported in 8 alpacas and one llama, demonstrating severe and frequently fatal encephalitis and introducing Eastern Equine Encephalitis as a differential diagnosis for camelids with CNS disease in endemic areas [30].

The cases diagnosed with mega-esophagus in this series had no identifiable cause. Speculation of possible factors has included spinal cord injury and repeated episodes of choke or trauma induced by jugular puncture. Traumatic damage to the esophageal innervation has previously been suggested as a cause of mega-esophagus [8].

Nine percent of cases in the current series had neurological signs, but no definite diagnosis was reached. Additionally, 3 cases were diagnosed with myelopathy of undetermined cause and one cria with severe congenital abnormalities associated with neurological disease. Further research is necessary to investigate degenerative myelopathy and myopathies. In such cases where exhaustive testing has not allowed a diagnosis to be made, the clinician needs to decide whether a neurological presentation is primarily neuropathic or myopathic in origin. Muscle biopsy may help differentiate the two. Advances in analytical testing will allow for more precise antemortem and post-mortem diagnosis of neurological conditions. Examples of testing modalities that were not readily available for work-up of the cases presented herein included magnetic resonance imaging (MRI), angio-CT (angiographic imaging with computed tomography), electroencephalograms (EEG), and brain biopsy.

\section{Conclusion}

In conclusion, llamas and alpacas can be affected with a wide range of neurological diseases. A number of which are in common with ruminant species such as listeriosis, polioencephalomalacia, grass staggers, and others, which are more in common with horses, including encephalitis from West Nile Virus and EHV-1. Additionally, they may be affected by diseases more peculiar to these species, such as llama adenovirus and meningeal worm. They appear to be more susceptible to cervical luxations and subluxations and heat stress than other species, and otitis tends to be more severe. Meningitis and, to a lesser extent, brain abscesses are an important complication of failure of passive transfer of immunity in crias. Similar diagnostic tools as are used in other species are available for use in camelids, and the CSF tap is especially useful for diagnosing meningeal worm and ruling out other diseases. When intracranial disease is suspected and CSF findings are not helpful, CT can be used successfully to diagnose intracranial masses, otitis media/interna, encephalitis, and hydrocephalus. Availability of magnetic resonance imaging should significantly improve the ability to detect soft tissue and vascular abnormalities that are hard to visualise on CT.

\section{References}

1. D'Alterio GL, Bazeley KJ, Pearson GR, Jones JR, Jose M et al. (2003) Meningitis associated with Salmonella Newport in a neonatal alpaca (Lama pacos) in the United Kingdom. Vet Rec 152: 56-7.

2. Frank N, Couetil LL, Clarke KA (1998) Listeria monocytogenes and Escherichia coli septicemia and meningoencephalitis in a 7-day-old llama. Can Vet J 39: $100-2$.

3. Goodchild LM, Dart AJ, Collins MB, Dart CM, Hodgson JL, et al. (1996) Cryptococcal meningitis in an alpaca. Aust Vet J 74: 428-30. 
4. Tsur I, Harmelin A, Dvir I, Yanai J (1996) Meningoencephalitis and brain abscessation due to Escherichia coli in a 2 week old alpaca cria. Aust Vet J 74: 437-8.

5. Van Metre DC, Barrington GM, Parish SM, Tumas DB (1991) Otitis media/interna and suppurative meningoencephalomyelitis associated with Listeria monocytogenes infection in a llama. J Am Vet Med Assoc 199: 236-40.

6. Twomey DF, Aktan I, Boon JD, Higgins RJ, La Ragione RM, et al. (2007) Streptococcus bovis biotype I meningoencephalitis in an alpaca (Lama pacos) cria. Vet Rec 160: 337-9.

7. Holmes LA, Frame NW, Frame RK, Duff JP, Lewis GC (1999) Suspected tremorgenic mycotoxicosis (ryegrass staggers) in alpacas (Llama pacos) in the UK. Vet Rec 145: 462-3.

8. Smith JA (1989) Noninfectious diseases, metabolic diseases, toxicities, and neoplastic diseases of South American camelids. Vet Clin North Am Food Anim Pract 5: 101-43.

9. Kutzler MA, Bildfell RJ, Gardner-Graff KK, Baker RJ, Delay JP, et al. (2004) West Nile virus infection in two alpacas. J Am Vet Med Assoc 225: 921-4.

10. Yaeger M, Yoon KJ, Schwartz K, Berkland L (2004) West Nile virus meningoencephalitis in a Suri alpaca and Suffolk ewe. J Vet Diagn Invest 16: 64-6.

11. Dunkel B, Del Piero F, Wotman KL, Johns IC, Beech J, et al. (2004) Encephalomyelitis from West Nile flavivirus in 3 alpacas. J Vet Intern Med 18: $365-7$.

12. Rebhun WC, Jenkins DH, Riis RC, Dill SG, Dubovi EJ, et al. (1988) An epizootic of blindness and encephalitis associated with a herpesvirus indistinguishable from equine herpesvirus I in a herd of alpacas and llamas. J Am Vet Med Assoc 192: 953-6.

13. Imai DM, McGreevey N, Anderson JL, Meece JK (2014) Disseminated Blastomyces dermatitidis, genetic group 2, infection in an alpaca (Vicugna pacos). J Vet Diagn Invest 26: 442-7.

14. Bertin FR, Taylor SD (2016) Cerebrospinal Nematodiasis in 20 Camelids. J Vet Intern Med 30: 1390-5.

15. Norton PL, Gold JR, Russell KE, Schulz KL, Porter BF, et al. (2014) Camelid heat stress: 15 cases (2003-2011). Can Vet J 55: 992-6.

16. SickingerM, Hirz M, Schmidt MJ, Reinacher M (2016) Dysuria due to discospondylitis and intervertebral disc herniation in a male alpaca (Vicugna pacos). Acta Vet Scand 58: 33

17. Hawkins IK, Ilha M, Anis E, Wilkes RP (2017) Septicemia and meningoencephalitis caused by Listeria monocytogenes in two neonatal llamas. J Vet Diagn Invest 29: 700-3.

18. Whitehead CE, Bedenice D (2009) Neurologic Disease in Llamas and Alpacas. Vet Clin N Am Food Anim Pract 25: $385-405$.

19. Chalkley MD, Kiupel M, Draper AC (2014) Pituitary Null Cell Adenoma in a Domestic Llama (Lama glama). J Comp Path 151: 51-6.

20. Barker WHJ, Witte TH, Driver CJ, Jull P, Whitehead CE, et al. (2015) Dorsal laminectomy for treatment of cervical vertebral stenotic myelopathy in an alpaca. J Am Vet Med Assoc 246: 1122-8.

21. Welles EG, Pugh DG, Wenzel JG, Sorjonen DC (1994) Composition of cerebrospinal fluid in healthy adult llamas. Am J Vet Res 55: 1075-9.

22. Dobey CL, Grunenwald C, Newman SJ, Muller L, Gerhold RW (2014) Retrospective study of central nervous system lesions and association with Parelaphostrongylus species by histology and specific nested polymerase chain reaction in domestic camelids and wild ungulates. J Vet Diagn Invest 26: 748-54.

23. Navarre CB, Heath AM, Wenzel J, Simpkins A, Blair E, et al. (2001) A comparison of physical examination and clinicopathologic parameters between sheared and nonsheared alpacas (Lama pacos). Small Rumin Res 39: 11-7.

24. Pinn TL, Bender HS, Stokol T, Erb HN, Schlafer DH, et al. Cerebrospinal fluid eosinophilia is a sensitive and specific test for the diagnosis of Parelaphostrongylus tenuis in camelids in the northeastern United States. J Vet Diagn Invest 25: 54-60.

25. Jackson C, de Lahunta A, Divers T, Ainsworth D (1996) The diagnostic utility of cerebrospinal fluid creatine kinase activity in the horse. J Vet Intern Med 10: 246-51.

26. Marriott MR, Dart AJ, Macpherson C, Hodgson DR (1999) Total ear canal ablation and lateral bulla osteostomy in an alpaca. Austr Vet J 77: $301-2$.

27. Koenig JB, Watrous BJ, Kaneps AJ, Adams JG, Parker JE (2001) Otitis media in a llama. J AM Vet Med Assoc 218: 1619-23.

28. Galbreath EJ, Holland RE, Trapp AL, Baker-Belknap E, Maes RK, et al. (1994) Adenovirus-associated pneumonia and hepatitis in four llamas. J Am Vet Med Assoc 204: 424-6.

29. House JA, Gregg DA, Lubroth J, Dubovi EJ, Torres A (1991) Experimental equine herpesvirus-1 infection in llamas (Lama glama). J Vet Diagn Invest 3: 137-43. 30. Nolen-Walston R, Bedenice D, Rodriguez C, Rushton S, Bright A, et al. (2007) Eastern equine encephalitis in 9 South American camelids. J Vet Intern Med 21: 846-52.

31. Rickard LG, Gentz EJ, Pearson EG, Smith BB, Frank AA, et al. (1993) Experimentally induced meningeal worm (Parelaphostrongyus tenuis) infection in the llama (Lama glama): clinical evaluation and implications for parasite translocation. J Zoo Wildl Med 25: 390-402.

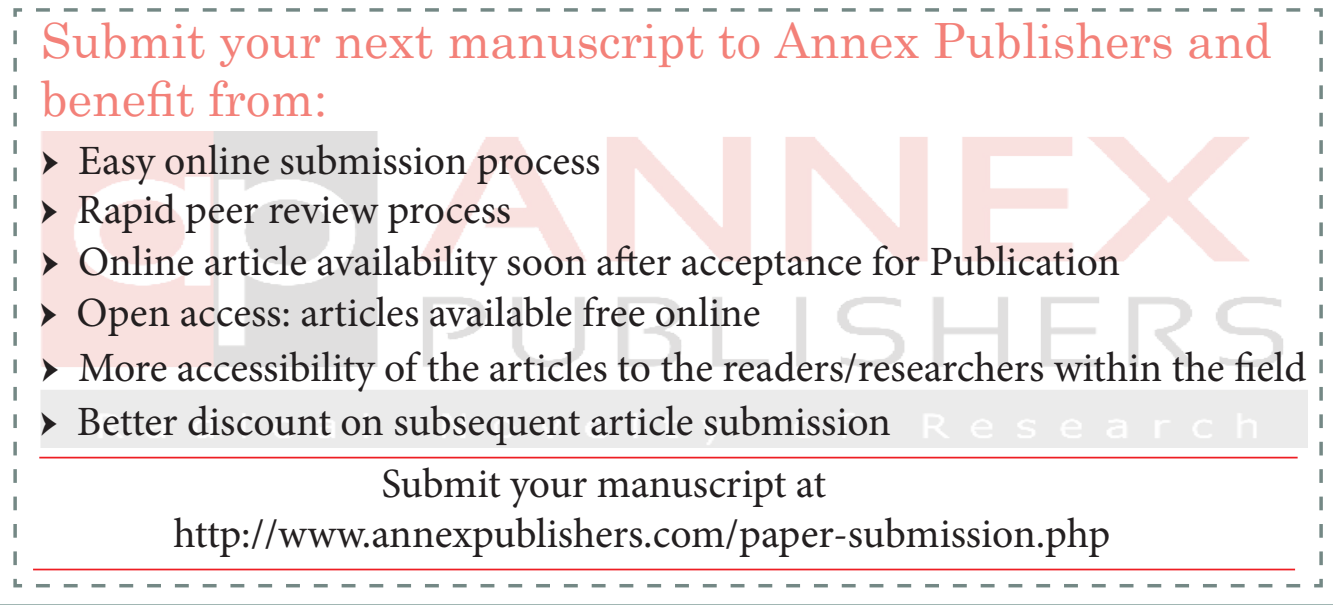

